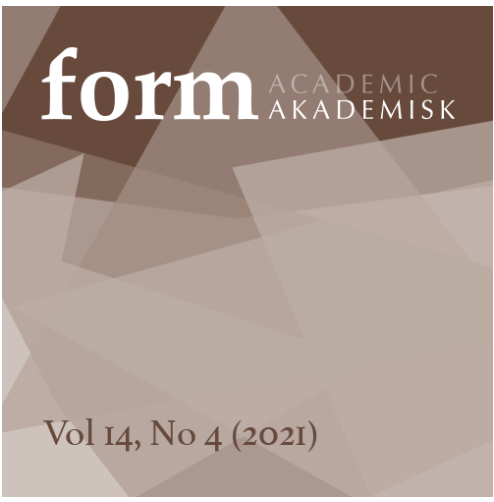

\section{Ingvild Digranes \\ Professor (PhD) \\ Western Norway University of Applied Sciences, Norway indi@hvl.no \\ Jon Øivind Hoem Associate Professor (PhD) Western Norway University of Applied Sciences, Norway Jon.Oivind.Hoem@hvl.no}

Arnhild Liene Stenersen Assistant Professor Western Norway University of Applied Sciences, Norway Arnhild.Liene.Stenersen@hvl.no

\title{
Learning about materiality through tinkering with Micro:bits ${ }^{1}$
}

\begin{abstract}
This paper discusses two pilot projects in Art and design education at the teacher training at Western Norway University of Applied Sciences. In the second round of drafts for the new curriculum of Art and design digital knowledge is described as stretching from using simple digital resources to master and shape your own digital products. It is no longer limited to two-dimensional visual modelling as previously drafted. This is in our view a new approach in a subject where making, tinkering and designing allows for explorations in both 2D and 3D. Given that we want to encourage the use of the digital together with the use of physical materials, the pilot case studies demonstrate the importance of bringing coding and the material aspects of tinkering, making, and creating into play. The BBC Micro:bit was used to make coding and mechanical control part of projects made with traditional material. Further research and development should be undertaken to bring such practices into classrooms in primary and lower secondary schools.
\end{abstract}

Keywords:

Art and design education, materiality, programming, Micro:bits, citizenship

\section{INTRODUCTION}

For many years, UNESCO has advocated the idea of citizenship education, which it describes as educating children from an early age to become clear thinking and enlightened citizens who participate in decisions of importance to society (UNESCO, 2010). In Norway Art and design is a compulsory subject throughout the ten years of primary and lower secondary school education. One of the aims explicitly stated for the education is that it should enable the children to take part in society, develop social and 
professional adaptability, and a democratic understanding (Meld. St. 28. (2015-2016)). Digranes and Fauske (2010) links the term to Art and design education and describe reflective citizen as a citizen who is capable of promoting a sustainable future through choices and actions. Design is increasingly seen as a one or the avenues or a way of thinking that can contribute to significant changes in the future (European Commission 2012).

The concept 'design literacy' is often used to explore and address the complex matter of objectives and content in design education from primary to university levels (Nielsen and Digranes, 2012). There has been a move in the professional field toward understanding design products and processes as composed of symbiotic hybrids between design products, media types, services, architecture, technology, programming, communicative spaces, networks and modes of creation, production, and exchange (Knutsen \& Morrison, 2010). The challenge will be to define the content and secure the implementation in existing and future practice in schools, when these thoughts are brought into the education at lower school levels.

\section{The Curriculum Renewal 2020 - Developing Art and design in Norway}

In Norway there is an ongoing process of renewal of the curriculum for primary and secondary schools meant to be finalised in 2020. In the white paper concerning this renewal; Fag-fordypning-forståelse: En fornyelse av Kunnskapsløftet. Meld. St. 28 (2015-2016). Several aspects, such as technological development in different professions, enhancing diversity, new forms of communication, the challenge with too many pupils not finishing secondary school, and the general development in the society, forms the basis for change.

In the drafts for the new curriculum of Art and design, the concerns voiced from the education milieus has been addressed. A highlighting of workshops and studio practice, as opposed to a more theoretical orientation, will serve to bring the focus back to making, designing and creating. Some of this will be anchored in more traditional craft processes and materials, however coding has been included and will be part of the new and wider concept of materiality that Art and design education will have to incorporate into the curriculum. Still without a clear definition coding can be understood as a higher level, more abstract way of working with the same concepts that characterise programming. But where programming tends to activities that produce new functionality, which a computer can use, coding is more about utilising existing functionality. As of now in the first draft, coding in Art and design is limited to two-dimensional visual modelling in lower secondary school (Udir, 2018). However, considering The Professional Digital Competence Framework for Teachers in Norway (outlined below) and the understanding of the reflective citizen that is design literate, to confine the digital or coding to the twodimensional picture plane is in our view a too limited approach in a subject where making, tinkering and designing allows for explorations in both 2D and 3D.

\section{Tinkering in Design Education}

The more traditional areas of Art and design, i.e. craft in wood and textiles or drawing, are well established in the school practice. Introducing programming and more intangible artifacts or products requires new approaches. In the introduction to his book Mindstorms (Papert, 1980) Seymour Papert reflects upon how computers can be a general tool for children to create for themselves. This view of creation is grounded in what Papert calls constructionism. This is an approach to learning where design experiences result in "objects-to-think-with", which are material objects that can also be internalized mental structures (Keune and Peppler, 2018).

In the future tinkering with computers might be an addition to the traditional tools: the "gears" for the new generation. The same is the case for a large variety of products and services - the digital transforms what was once mechanical into hybrid constructions, controlled by computers. The idea of tinkering (Resnick, and Rosenbaum, 2013) has followed humans as long as we have had a relationship to tools. Tinkering, playing with the possibilities given by available tools, has always been a winning strategy for innovation. We may, however, argue that tinkering has become increasingly important, in a world characterized by rapid change. 
Education is never static, rather it is fluent, flexible and diverse. A lot depends on the teachers and the day-to-day practice in both formal and non-formal education, and the policy that binds them. A EU report from 2012 named Design for Growth \& Prosperity. Report and Recommendations of the European Design Leadership Board. European Design Innovation provides 21 recommendations for the future development of design and design education in Europe (European Design Leadership Board, 2012). Recommendation 20 is to: "Raise the level of Design literacy for all the citizens of Europe by fostering a culture of "design learning for all" at every level of the education system" (European Design Leadership Board, 2012, p. 73). In some newer educational research within Art and design education the focus has been on what makes it meaningful for the pupils, an as such in teacher training. Approaching design in schools, educational theory of the students' design process emphasizes their ability to carry out a whole creation process, from idea to finished product. Randers-Pehrson's research into Norwegian upper secondary school in Art and design education addresses something similar in her concept of "thing-making". She sums it up as: The Experience and mastering of the material seems to be one of the driving forces for the students' work. (. ... ) As such, the 'thing-making' is a meaningful activity, because it is given shape and becomes 'something'... (Randers-Pehrson, 2016, p. 280). The one factor we aimed to hold constant was that the focus would be on problem-solving, designing solutions, and the aesthetics rather than just the coding. Designed artifacts can be seen as a type of communication and storytelling in itself, and youth move seamlessly between the divide that the curriculum coins analogue and digital (Mäkelä, 2011). However, knowing that pupils value the traditional crafts highly we also need to acknowledge that student engagement and motivation are enhanced through integration of new technologies in education (Smeda et al., 2014). As the pilots unfolded, we saw several areas of discussion in regards to reaching this further ambition, and a plan for improvement emerged.

\section{STRATEGY AND METHOD}

This paper discusses two pilot projects, fall 2018 and spring 2019, in Art and design education 101 at the teacher training at Western Norway University of Applied Sciences. In both pilots we used the BBC Micro:bit to make coding and mechanical control part of projects made with traditional materials. One of the strengths in doing a case study is that it is a strategy more than a set of methods for gathering data. "As a form of research, case study is defined by interest in individual cases, not by the methods of inquiry used" (Stake, 2000 p.86). From what Yin (2003) and Stake argue, if you manage to identify the case, the methodology will follow as a result of your focus and what you would like to study about that specific case and in light of your chosen theory. A case study gives the frame of context, when your question deals with how and why in the present, and allows for a deeper understanding of a specific area, in this case how tinkering with Micro:bits can strengthen the digital and material knowledge the student teachers and how and why this approach in itself can be useful in meeting challenges in their future classroom practice. One of the dilemmas in this study is that we would be researchers as well as the educator. We were focusing on being aware of our different roles in the project at all times. To not force our expectations on the situation or other stakeholders did not pose to much of a challenge, as we also went into the pilots without really knowing what to expect. Working within the known boundaries of teaching design studio, programming was introduced as a new factor. Not limiting the approach but keeping it an open case approach let the involved parties to gather several avenues of data, from teacher logs, student logs, observation notes, photos of project drafts and student works, we let the case inform the data collection (Yin, 2003).

\section{Pilot 1a, $1 \mathrm{~b}$ and Pilot 2}

The study consists of two pilots. The pilots were short projects to see how coding through Micro:bits could be part of an aesthetical exploration in art and design rather than just a technical introduction. The purpose of the pilots was to find out appropriate ways for how the future teachers in Art and crafts could get experience with coding and programming in a task that was placed in the context of traditional methods, issues and thinking of the subject Art and design. There were no clear expectations to how the student teachers might perform, or if the framework would work, or the hardware would perform. 
It was a test of what we would work with in terms of resources on all levels, human, knowledge, hardware, code, etc.

Pilot 1 was completed with students in their third year of teacher education. It was split into two parts. The first phase (1a) was a short introduction where they only used some basic functionality on the Micro:bit working with "artist books". Abandoned books were transformed by the students, changing their physical attributes and adding visual, tactile and digital components, all part of a story made of fragments from Alice in Wonderland. As part of their books the students were told to use a Micro:bit and a battery pack as an integrated part of the book (Figure 1 and 2). This approach was designed to be relatively simple, only an introduction to the Micro:bit and how it can be coded. Most students chose to display some kind of message, related to the Alice-narrative, using the LED-display that is integrated into the Micro:bit. The time frame given was six days. The assignment did, however, include a number of digital tools. Every student was working with their own book and the physical integration of the Micro:bit, but they could cooperate when it came to the development of the code.

This group of students were given a more complex assignment a few weeks later (Pilot 1b). This time the students were introduced to different ways of approaching meaning in works of art. The students were then divided into groups of three and the assignment was to create a situation / object in a public place where a viewer can be included in interaction with an 'artist robot'. The students were given to following assignment: Use one or several Micro:bits to control a 'robot' that take part in the creation of an artistic expression. This expression should be produced over time, through an interaction that either facilitate an artistic experience or manipulate an artistic material. The time frame was six days, but the students did only get guidance from teachers the first two days.

The second pilot, pilot 2, was completed with students in their first semester. They had both the introduction and a more complex assignment in a continuous period. The assignment was to: ... design a kinetic sculpture for a wall. Through problem solving you will construct a wall hanging sculpture that can be activated by a spectator. You will consider these aspects: volume - it is three-dimensional, movement - actual or alluded, programming will be a part of the movement, and you will consider the spectator role in activating the sculpture. Inspiration has to be taken from organic forms or Sami craft. The timeframe was 3-4 days, with teachers involved mainly in day 1 and 3.

The data in the pilots consists of reflection notes from the lecturers, logs written by students, discussions, and photos/films of student works. The student teachers become valuable sources of knowledge. Even though the pilots had a limited scope in terms of time, data, and problem framing, they provided valuable insights towards the design of the main projects to come.

\section{Working with the BBC Micro:bit}

The BBC Micro:bit is a handheld, programmable micro-computer, introduced in 2015 and given to 7th graders in the UK. The device has a lot of different functions integrated in a small unit (see Figure 1). The device does also have a large number of connectors, which makes it possible to use the Micro:bit in a huge variety of projects.

The Micro:bit is considered useful for several reasons: it is cheap, all coding can be done online, and no installation is required. The projects can be kept simple, or easily be made more complex through more advanced code and by adding periphery units that can send and receive signals through the Micro:bits edge connector-pins.

The Micro:bit is programmed through a modified version of Microsoft's TouchDevelop platform, a web-based service hosted at www.makecode.org that allow programming from many devices, including smartphones and tablets. Makecode.org provides an interface that is very similar to and makes skills learned in e.g. Scratch easily transferable, and vice versa. 


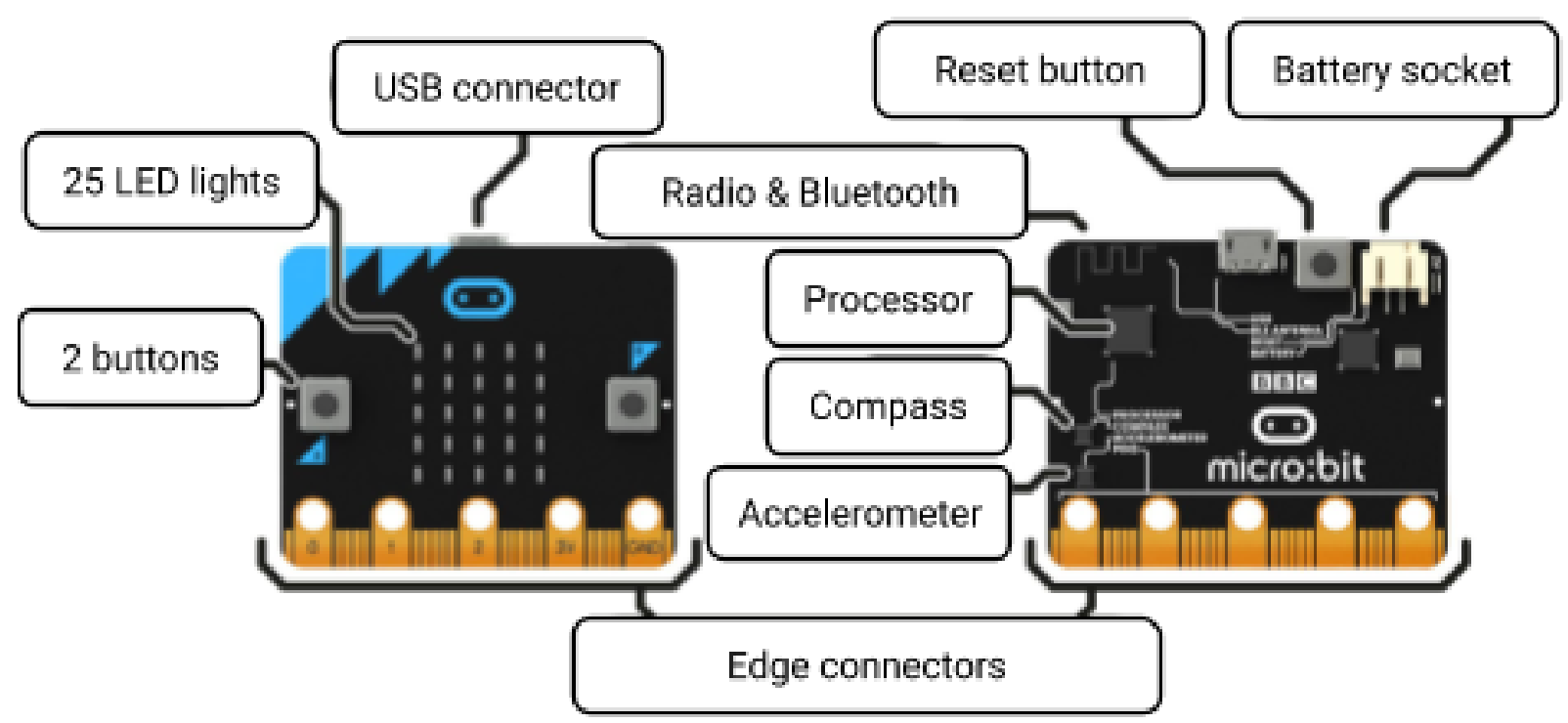

FIGURE 1 The BBC Micro:bit, a small computer using components developed for mobile devices. The row of edge connectors at the bottom makes it possible to integrate the Micro:bit with a large variety of external devices.

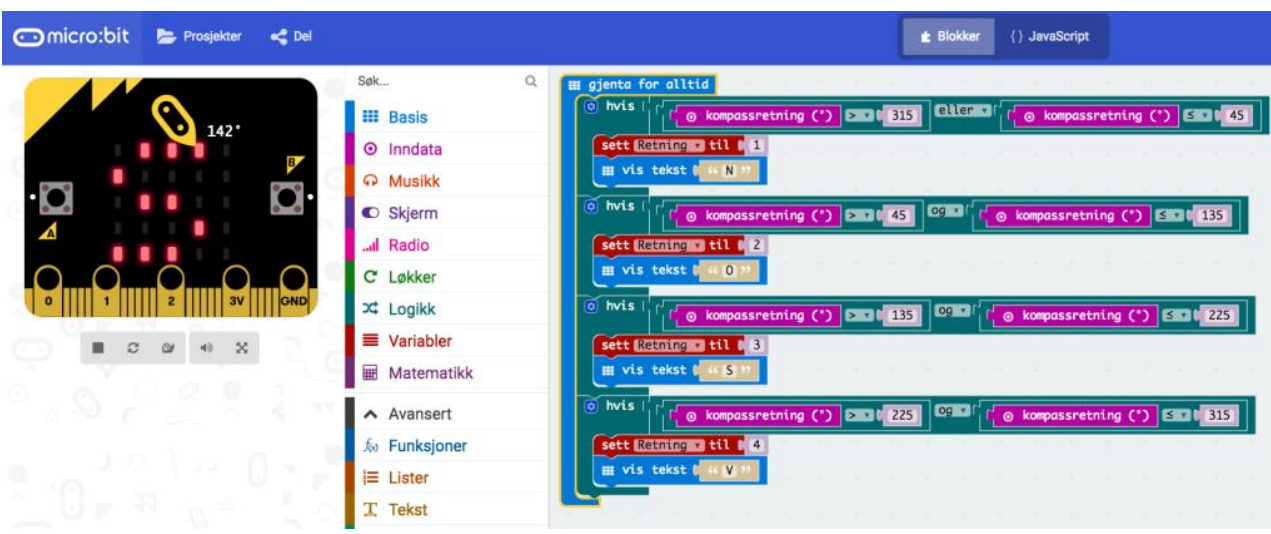

FIGURE 2. An example of code developed in project 1a when the students worked with integrating the Micro:bit in books. This script was used to write different messages into the LED-display when the book is turned.

\section{ANALYSING THE PILOTS \\ Pilot 1}

The first introduction to Micro:bits (Pilot 1a) was related to the students working with inspiration from artists books. The coded messages were mostly activated by using the Micro:bit's buttons, but some used the light sensor, the accelerometer or the compass. The scripts were, however, short and straightforward, and most of the students limited their coding to minor modifications of existing code. However, this pilot fulfilled its purpose by introducing the Micro:bit's possibilities, the concept of coding online and transferring the program to the Micro:bit, as well as integrating the device into an existing physical object (Fig 1 and 2).

Pilot $1 \mathrm{~b}$ involved experiments with the possible interaction between the Micro:bit, the code, the material, the site of the performance and the viewer(s). In this project we saw how the Micro:bit, also have material qualities of their own. Working with digital tools can be said to have its own language and materials, including physical interfaces like wires, buttons, connectors, lights, switches, sensors etc. The material that come from the digital domain may contrast the more traditional materials we are accustomed to in Art and design, but the different materials do also blend and sometimes merge into unity. In this project we saw how the new materials meet and contrast the old, familiar materials and 
some of the groups saw their existing practical knowledge in new light through the encounter with Micro:bits.
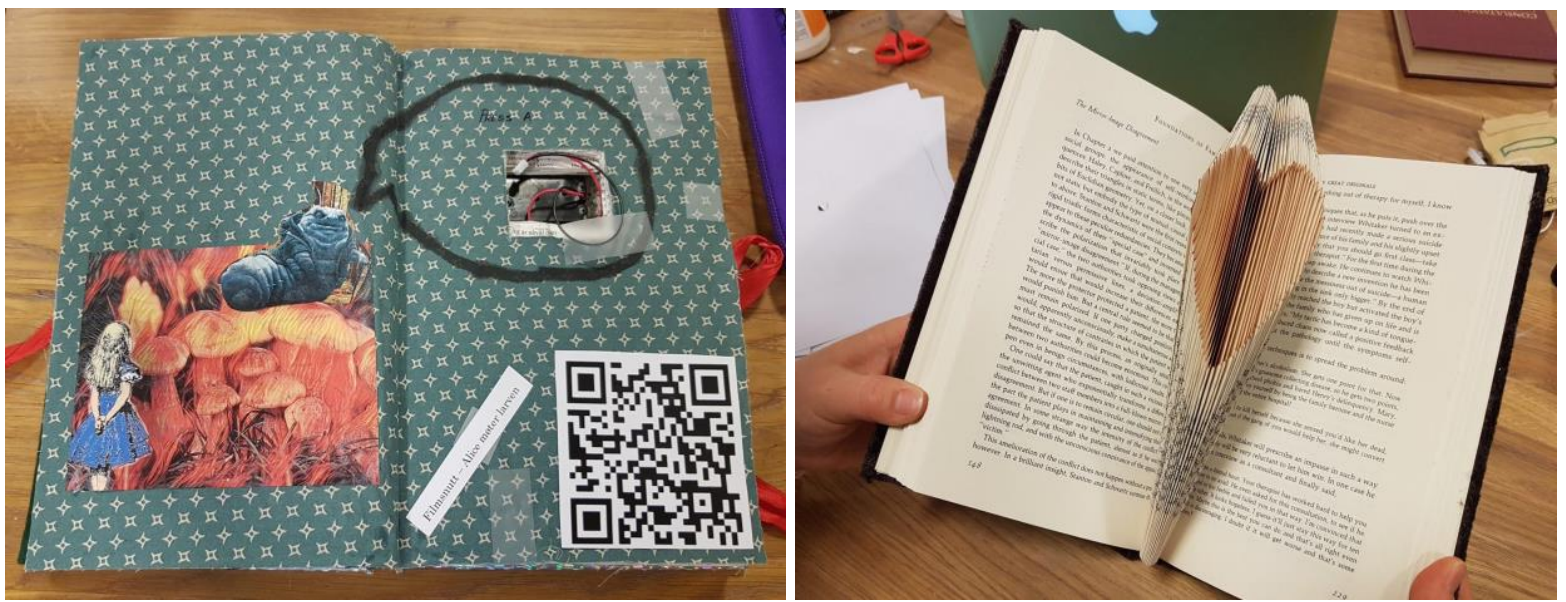

FIGURE 3 AND 4. Several visual elements playing along with the Micro:bit (inside the speech bubble that is going to be all black). The QR-code is used to trigger information presented as Augmented Reality (Figure 3). A highly decorative element, which in addition to communicate meaning can also serve a practical purpose: in this case a hiding place for the battery pack that power the Micro:bit (figure 4).

At first glance the Micro:bit is a device with some significant limitations. However, the versatility of coding introduces a level of flexibility that made the students able to come up with very different solutions to the assignments. In Project $1 \mathrm{~b}$ they were to produce a "robot" capable of assisting in the production of artistic expressions. An example is a group that came up with a solution meant to mechanically transfer paint through soap bubbles, from small cups on to a canvas. The physical setup and coding were relatively straightforward, and the students had a working prototype after a few hours. However, when the digital materials met the traditional, physical materials the students faced several challenges. The group did a long series of experiments with various mixtures of paint and soaps. Because they had to make the interplay between the mechanics and the physical material work, there was no quick fix, and the students explored the materials in a way that is very unlikely to have happened with a more traditional approach to painting.
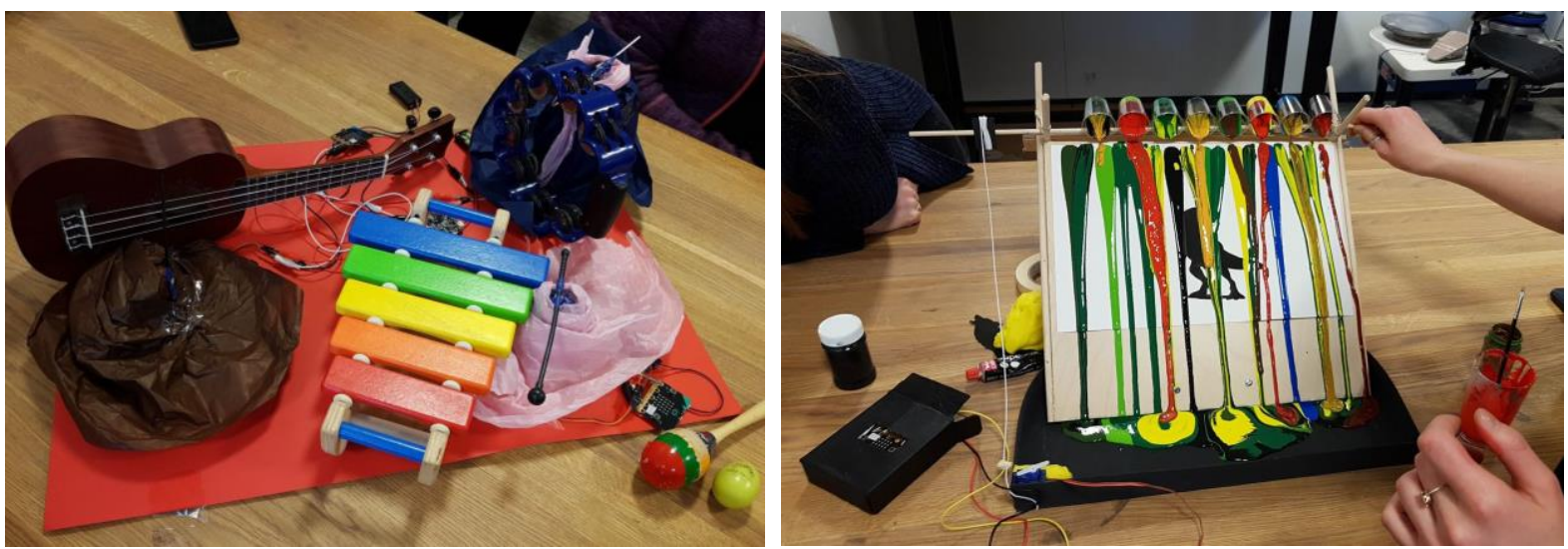

FIGURE 5 AND 6. Several Micro:bits used to control servos that are connected to various physical extensions, each designed to make an instrument play (figure 5). Another creation made during project $1 \mathrm{~b}$. This group was tinkering with the interplay between gravity and viscosity of paint. They also had to figure out how to construct a lever to make the servo(s) strong enough to control the small paint buckets (figure 6). 
It is worth noting that the code used to control the servos for the music playing project, shown in figure 5 , was very similar to the soap bubble machine. Still the final expression is very different. In the music playing project one of the major challenges was to make three different servos move in a way that created a consistent rhythm. This was difficult because the servos did not perform exactly similar, and drifted out of sync. Still, this drifting created new sound patterns that, at least from the teachers' point of view, became more interesting than a monotonous rhythm.

Out of several interesting projects the one shown in Figure $8 \mathrm{~b}$ may serve as another example to how the material challenges were handled by the students. This group did a good job when it came to the concept and the early prototyping, and they had a clear vision for the final result. Here there is a lot of physics in play. The students had to attaching a small leveller to the shaft to transfer the servo's movement into a rotating motion. In this case the design failed a little, as the prototyping was done without paint in the small cups attached to the shaft. When the cups were filled it became evident that a longer leveller was needed to make it easier to pull by the servo, something that would require a slightly different construction. Again, a lot was learned about the different material qualities during the process.

In Pilot 1, the Micro:bit is interesting out of a number of reasons. First and foremost, it promises to bridge a gap between artistic expressions and coding - allowing the computer to take part in artistic expressions. Even though concepts like algorithmic art goes back several decades, arguably as long as we have had digital computers (Verostko, 1994), there is still a weak connection between most art made with digital tools and coding, done by the artist.

Various ways of so-called creative production draw heavily on re-use existing material and ideas from already existing works. One can argue that the information society do favour those who are able utilise existing works to develop strategies to collect and process existing information and reformulate it in order to meet personal needs (Hoem \& Schwebs, 2005). Re-use is a common practice in all creative work. However, among professionals like "filmmakers, visual artists, photographers, architects and Web designers (...) this is not openly admitted, and no proper terms equivalent to remixing in music exist to describe these practices" (Manovich, 2002).

Almost all authoring and editing software comes with a large number of predefined functions. Therefore, substantial parts of "creative" production become a direct result from selection among predefined functions. The Micro:bit is different and provides another, yet relatively simple, approach to creative creation. Code can easily be found and copied, and the remixing of code becomes one of the essential parts of the creative process. This was clearly demonstrated when some of the students in this case study brought their newly acquired skills into their internship.

\section{Pilot 2}

In Pilot 2 the students had three to four days to work with the tasks at school, where they received guidance from the teachers. This group, students in their first, year had an introduction and worked on their more complex assignment during the one scheduled period.

To focus of the assignment in pilot 2, was to see if the students could produce a design where the Micro:bit and programming could enhance the aesthetic qualities of a kinetic sculpture. The focus on volume, movement and interaction with an audience was the primary focus, and there brief also stated the source of inspiration as organic forms or Sami craft. The motivation for this was to frame the exploration in a way that would challenge through boundaries. This brought some contrasts to view.

The first-year students had worked throughout semester with more traditional introduction assignments in different modes of drawing, painting, sculpting and visual narrating. There was a marked resistance to risk taking, and they all had expectations to the assignments in terms of "what I have seen before and would like to be able to do". They kept measuring themselves and their solutions to the known, and getting them to explore materials and play with solutions proved demanding. Even as the brief in Pilot 2 can be seen as 'traditional' in Art and design education, i.e. playing with form and composition, volume, materials, inspiration, and addressing a spectator or user etc., the fact that we introduced an unknown material and tool, the Micro:bit with add-ons, it freed the students from desiring a specific outcome. In the idea phase, the groups were willing to explore several different sour- 
ces of inspiration, different ideas on activation and movement, and kept going back and forth between ideas, sketches, prototyping and adjustments.
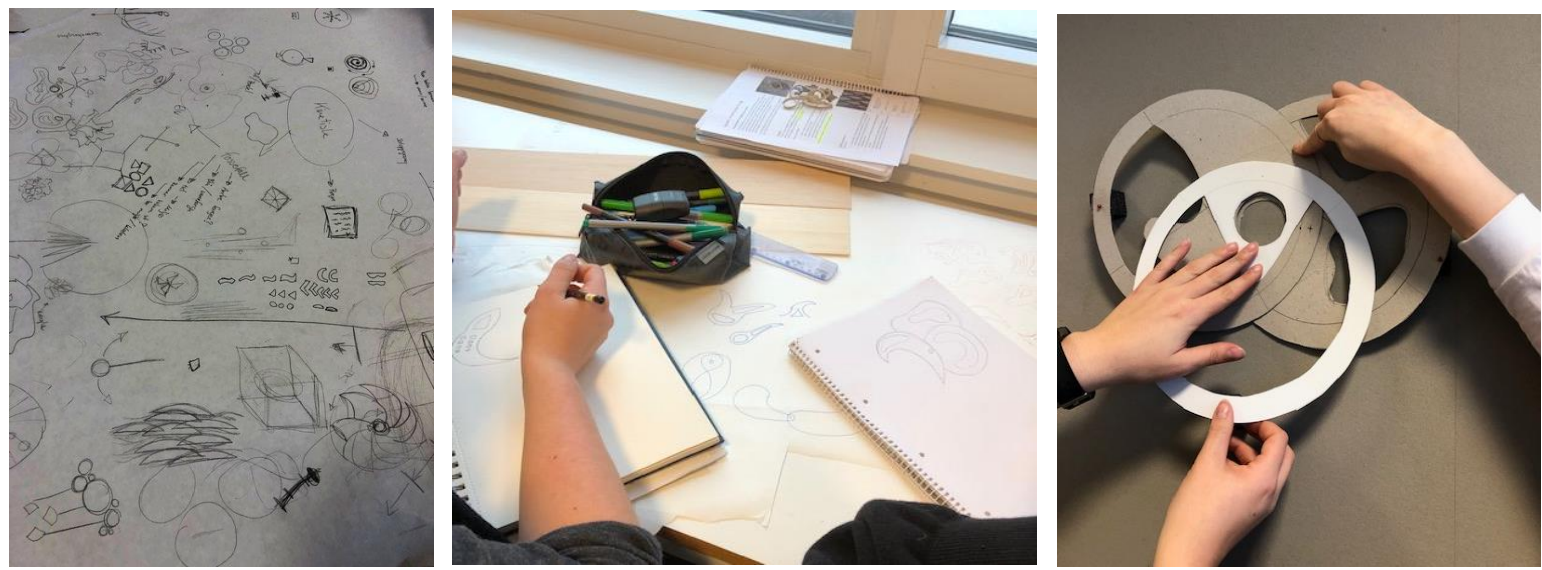

FIGURE 7. One of the groups that played back and forth with form, movement, inspiration, and materials.

Among the more unexpected findings were how the students did explore different physical materials to make this work with the digital material - including the physical Micro:bit, the servos and the code. In his book The reflective practitioner: How professionals think in action, design theorist Donald Schön characterise tinkerers as people who have a conversation with the material (Schön, 1983). We could clearly observe such conversational among the groups of students in our case studies, when students were working back and forth between code, servos and the various building materials.

Even though the individual elements can be considered simple, the students were working with assignments that they developed into solutions that became quite complex. They should learn how to program the Micro:bit, sometimes make several Micro:bits work together, and figure out how to make the elements of the artefact do the movement(s) the way it was intended by the design. The students should also deal with the formal aesthetic means, and in some cases, they also integrated a message in their work with creating an artefact. Most of the students also worked with physical materials that they had not, or just to a small extent, previously met.

A limitation that influenced on the students' work were the selection of artistic materials. One of the projects, the branches of a tree were meant to rotate horizontal, but the servos could not manage it because of the total weight of the textile leaves and friction towards the back wall. If these textile materials were changed with lighter materials, the servos could have managed the rotation. There were also other examples that showed the need for a greater selection of materials in the students' process, and more time to get familiar with the limitations or possibilities of the materials. One of the student projects wanted to rotate a spiral to create an illusion of moving colour, but because of the format and the weight of the chosen material the spiral became too heavy to successfully rotate as planned. With another choice of a material the movement in the spiral and the aesthetic form itself, could have been clearer, and also made the rotation easier for the servo.

However, these trial and errors show that the students took the challenge given in the assignments, which was to learn something new about integrating Micro:bits as a material element. It was also allowed the making of kinetic sculptures that didn't end up working as the students planned in the beginning of the project. The students had been through a problem-solving process, a learning process regarding the materials' limitations, and reflections on what would, and would not, work teaching coding in primary and lower secondary schools. 


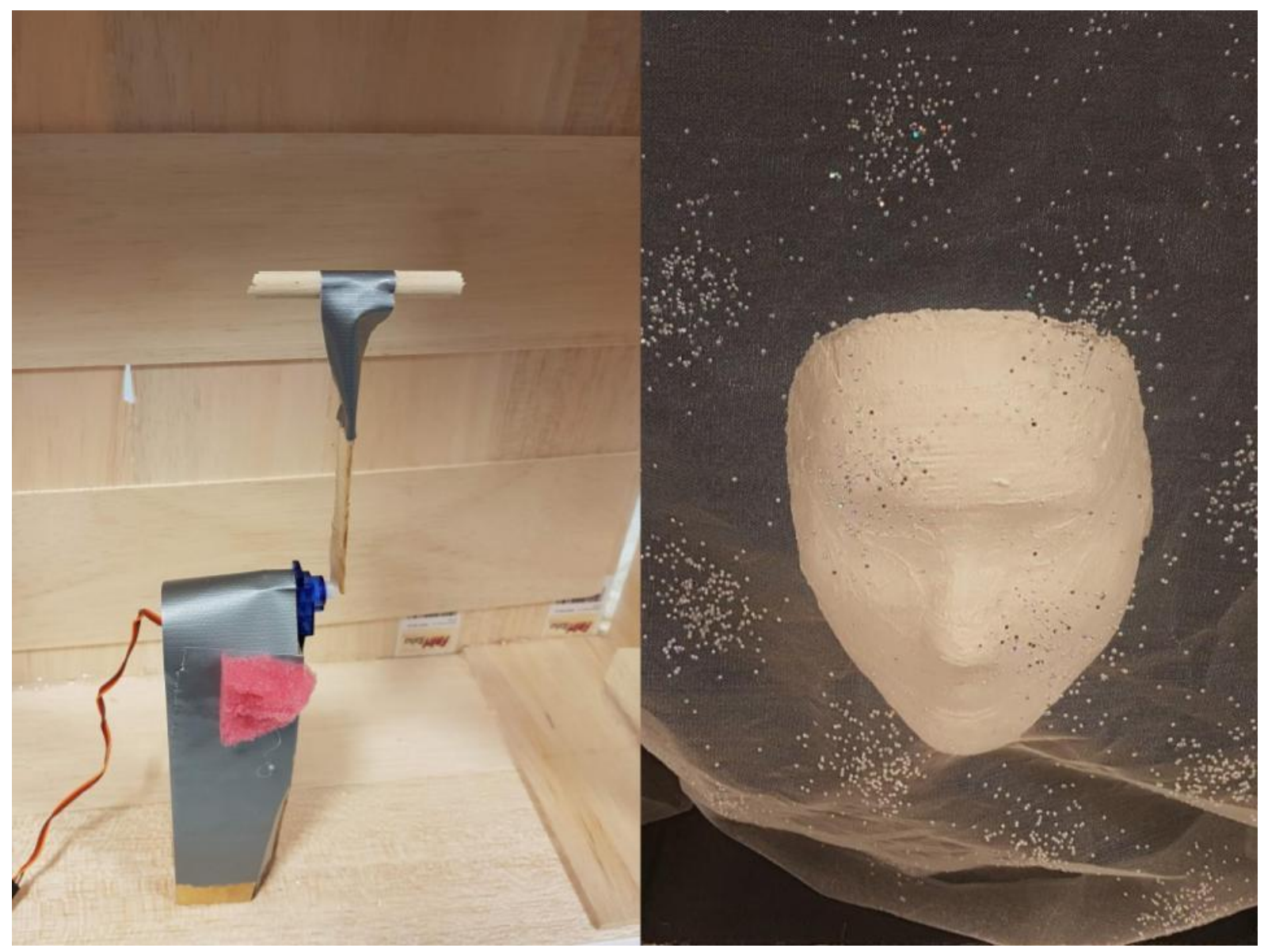

FIGURE 8A AND 8B. The length of an arm (a) had to be a tradeoff between the distance the plaster face (b) could be pushed and the strength of the servo. The weight of the face and the material the face is pushed into, also have to be considered.

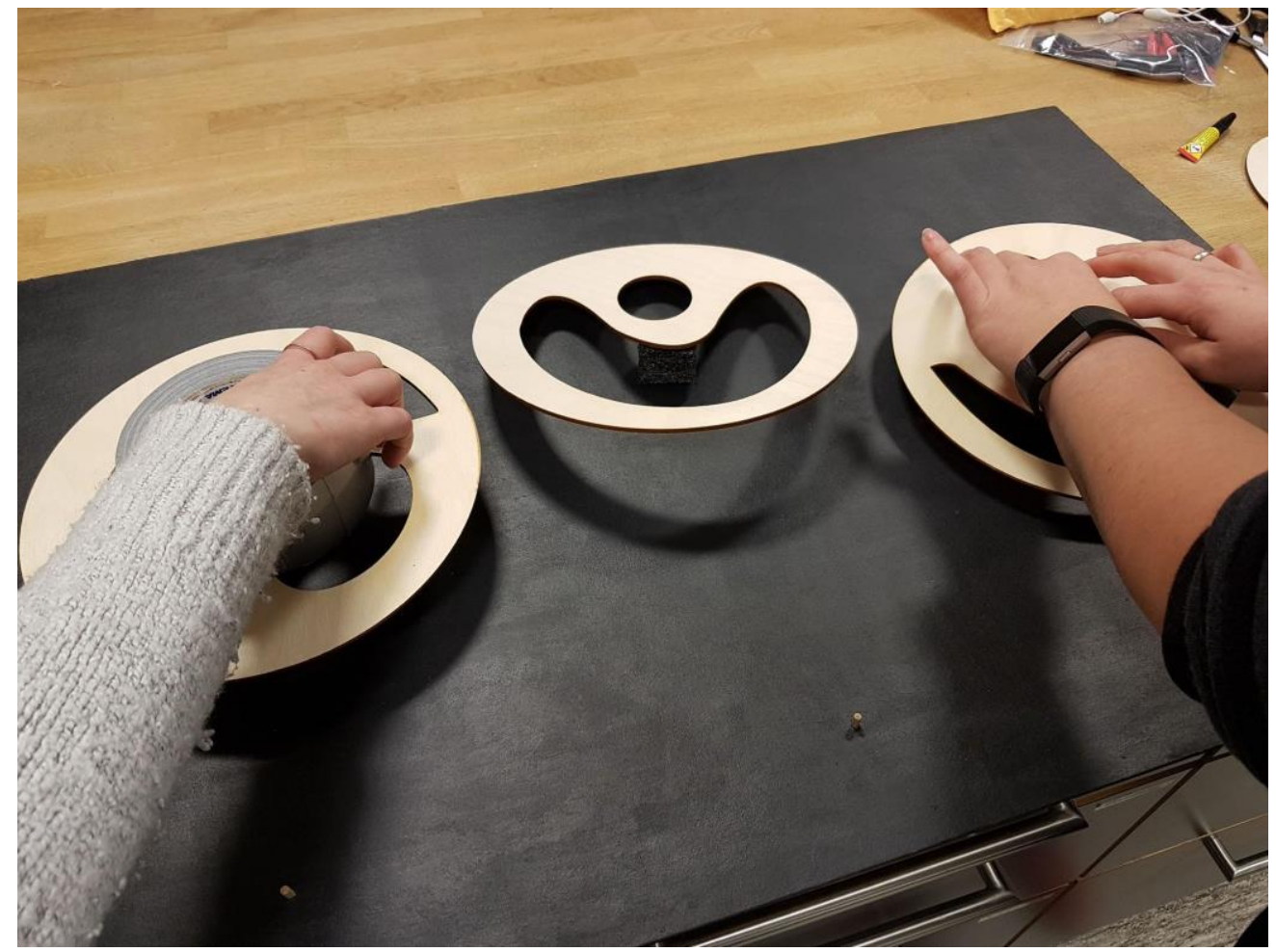

FIGURE 9. Three related shapes, drawn as vector graphics and cut on a laser cutter at a nearby makerspace. In this case, the students had to adjust their original concept with servos off center and put the shaft as close to the center of gravity as possible. 
Another, unexpected finding was in regard to the finished student work, the students' attachment in light of the work process, and the execution of the finished work and effort to match the brief. One of the challenges in general education is that if the projects become too conceptual, pupils fail to see the value in the finished product. As one of the fundamental challenges facing the subject is sustainability, the idea of creating waste in the classroom is not pleasant. Though learning process, risk-taking, play, experimentation, and knowledge of both materiality and the digital is valuable, when considering what the pupils, and the student teachers' find as meaningful works. Looking at the student work in Fig. 8 and 10, the work in Fig. 8 did not really originate as much from the inspirational sources listed in the brief. The approach was similar to one where the students locked themselves in one idea, and the process of design was connected more to the technical aspect than the aesthetic solution. However, the student work in Fig. 9 was based almost solely on organic form, and every choice, in a very complex back and forth process, was made to enhance this aspect. At the end of the exhibition, the group Fig 8. threw their work out first chance they got, while the other carefully wrapped the pieces and discussed how they could be used as concrete models in later educational practice. This is something to consider in framing the assignments in terms of introducing them into the overarching topics of sustainability in Fagfornyelsen 2020 Professional renewal 2020] (Udir, n.d.).

Given that we want to encourage the use of digital tools across topics and involving the use of physical materials, we do believe the pilot case studies demonstrate how the importance of bringing coding and related activities out of the data lab. When teachers are able to turn their classroom into something that becomes more like a makerspace, where the digital and the material aspects of tinkering, making, and creating with new technologies come into play. The further research, not undertaken as of yet, will be a collaboration with Bergen municipality, where we bring the project to the practice with classroom teachers, student teachers, and pupils in their internships in primary and lower secondary schools.

\section{SUMMING UP}

Future teachers need to be confident in their relationship with and use of technology. As with any material and/or tool this requires training and the individual development of new skills. However, the most important skills are not directly related to individual knowledge and the ability to master technical features. From our point of view, seen from Art and design education, what is most important is to give students an overall confidence towards tinkering - experimenting with technology in ways that do not always need to fulfil a specific goal.

When observing the use of Micro:bits in schools and among our students, most examples are very simple when it comes to the actual code. On the basis of previous observations of practices in schools we initially assumed that students would find existing resources and copy code. This assumption turned out to be the case among all the groups in our case studies. Only those working with very simple code did all the coding by themselves. The vast majority found example code and did modifications - a kind of remixing, as known from computer culture in general. However, this does not mean that the Micro:bit only allow relatively simple coding. We see the students' use more as an expression of the Micro:bit's ability to raise awareness of material qualities in objects that surrounds it. What is really nice is that it provides a point of entry, into coding, even for students that have no previous experience with this way of using computers.

In the process of working with complex problems there is an interplay between a variety of materials. As a result, the process will lead to solutions that teachers and students were not at all aware of at the beginning of a project. Thus, the design process becomes most important and the ability to reflect upon how the various materials constantly influence and change each other, as well as the understanding of the initial problem.

The practical educational solutions to secure learning outcomes in interplay with the knowledge aims of Fagfornyelsen 2020 [Professional renewal 2020] (Udir, 2019) lies within the every-day execution of subject content, as implemented by classroom teachers, the next generation student teachers, and the educators in teacher training. In this study we have shown several approaches towards anchoring 
the new knowledge aim of coding in the subject Art and design. When looking ahead, the tinkering with digital technology and physical constructs, to solve design problems, can be seen in a larger context, related to the overarching themes i.e., citizenship and sustainability through design. To manage these tasks teacher education needs to facilitate tinkering and encourage students to experiment. In a sustainable manner, teacher training must let students develop their knowledge to make them more capable of taking part in shaping the use of software and related technologies. The ability to define problems, explore different solutions and come up with a functional design, and finally implement a working prototype becomes a skillset that can prepare students for problem solving in general. The students learn that solutions are not something they can get from specific sources, but something they have to actively engage with through the combination and adaptation of information and knowledge from several sources.

To an increasing degree we develop a more dialogical relationship with digital technology. This has consequences for almost all technical devices, because they are controlled by software. In the future, those who learn to master these dialogues with digital machines will have an advantage. At the same time technology must be managed, mastered and controlled. Increased civic insight and ethical perspectives are seen as important elements in education, and Art and design education is in a position where we need to face the challenges within teacher training (Udir, 2018). The teachers we educate today will be among those who educate children and young people into this future. We need to equip these students for what is coming, and teacher education must therefore develop a greater practical understanding of how software affects our physical surroundings. The material focus and awareness Art and design can promote in regard to consumption, innovation and entrepreneurship in an ethical setting, becomes one of the arenas that we will have to strengthen. In doing so we have to fully acknowledge the increasing influence and integration of the digital and traditional materials. 


\section{REFERENCES}

Digranes, I., \& Fauske, L. B. (2010). The Reflective Citizen - General Design Education for a Sustainable Future. In C. Boks, C. McMahon, W. Ion, \& B. Parkinson (Eds.), When Design Education and Design Research Meet. The 12th International Conference on Engineering and Product Design Education (pp. 364-369). The Design Society. https://hdl.handle.net/10642/539

European Commission. (2015). Science Education for Responsible Citizenship. http://ec.europa.eu/research/swafs/pdf/pub_science_education/KI-NA-26-893-EN-N.pdf

European Design Leadership Board. (2012). Growth and Prosperity (Report and Recommendations of the European Design Leadership Board). http://europeandesigninnovation.eu/wpcontent/uploads/2012/09/Design_for_Growth_and_Prosperity_.pdf

Hoem, J. and Schwebs, T. (2005). Personal publishing and media literacy. http://hdl.handle.net/11250/2481567

Knutsen, J., \& Morrison, A. (2010). Have you heard this? Designing mobile social software. FormAkademisk, 3(1). https://doi.org/10.7577/formakademisk.188

Meld. St. 20 (2015-2016). Fag-fordypning-forståelse: en fornyelse av Kunnskapsløftet [Subjects specialization - understanding: a renewal of the Knowledge Promotion]. Kunnskapsdepartementet. https://www.regjeringen.no/no/dokumenter/meld.-st.-28-20152016/id2483955/sec1

Manovich, L. (2002) Who is the Author? Sampling / Remixing / Open Source. http://manovich.net/content/04projects/035-models-of-authorship-in-new-media/32_article_2002.pdf

Medietilsynet (2018). Barn og medier undersøkelsen 2018: 9-18 åringer om medievaner og opplevelser [Children and media survey 2018: 9-18-year-olds about media habits and experiences]. https://www.medietilsynet.no/globalassets/publikasjoner/barn-og-medier-undersokelser/barn-ogmedier-2018-oppdatert-versjon---oktober-2019.pdf

Mäkelä, E. (2011). Slöjd som berättelse - om skolungdom och estetiska perspektiv [Handicraft as a story - about schoolchildren and aesthetic perspectives]. (Doctoral dissertation in Pedagogical work, no. 41, Umeå universitet). https://www.skolporten.se/forskning/avhandling/slojd-som-berattelse-om-skolungdomoch-estetiska-perspektiv/

Nielsen, L. M., \& Digranes, I. (2012). Designkompetanse i et gjennomgående utdanningsløp [Design competence in a continuous educational course]. Techne series : Research in sloyd education and crafts science. A, 19(1), 17-24. https://journals.oslomet.no/index.php/techneA/article/view/394

Papert, S. (1980). Mindstorms: children, computers, and powerful ideas. Basic Books.

Randers-Pehrson, A. (2016). Tinglaging og læringsrom i en kunst- og håndverksdidaktisk kontekst ['Thing-making' and learning space in an Art and crafts educational context]. (PhD, University of Oslo). http://urn.nb.no/URN:NBN:no-56700

Resnick, M., \& Rosenbaum, E. (2013). Designing for Tinkerability. In M. Honey \& D. Kanter. (Eds.), Design, Make, Play: Growing the Next Generation of STEM Innovators (pp. 163-181). Routledge. https://doi.org/10.4324/9780203108352-15

Keune, A. \& Peppler, K. (2018). Materials-to-develop-with: The making of a makerspace. The British Journal of Educational Technology, 50(1), 280-293. https://doi.org/10.1111/bjet.12702

Schön, D. (1983). The reflective practitioner: How professionals think in action. Maurice Temple Smith.

Smeda, N., Dakich, E., \& Sharda, N. (2014). The effectiveness of digital storytelling in the classrooms: a comprehensive study. Smart Learning Environments, 1(1), 1-21. https://doi.org/10.1186/s40561-0140006-3

Stake, R. E. (2000). Case studies. In N. K. Denzin \& Y. S. Lincoln (Eds.), Handbook of qualitative Research (pp. 86109). Sage Publications.

Udir. (2018). Professional Digital Competence Framework for Teachers. https://www.udir.no/globalassets/filer/inenglish/pfdk_framework_en_low2.pdf 
Udir. (2019). Fagfornyelsen 2020. Høring på Kunst og håndverk. [Knowledge Promotion 2020. Hearing on Art and Crafts] https://hoering.udir.no/Hoering/v2/341?notatld=680

Udir. (n.d). Core curriculum - values and principles for primary and secondary education. https://www.udir.no/lk20/overordnet-del/?lang=eng

UNESCO. (2010). Citizenship Education for the 21st Century. http://www.unesco.org/education/tlsf/mods/theme_b/interact/mod07task03/appendix.htm

Verostko, R. (1994). ALGORITHMIC ART. Composing the Score for Visual Art. http://www.verostko.com/algorithm.html

Yin, R. K. (2003). Case study research. Design and methods (3rd ed.). Sage Publications.

\footnotetext{
${ }^{1}$ First published as Digranes, I, Hoem, J. Ø. \& Stenersen, A. L. (2019). Learning about materiality through tinkering with Micro:bits. Conference Proceedings of the Academy for Design Innovation Management, 2(1). The article is republished with permission.
} 